\title{
Role of Public Investment in Growth and Poverty Reduction in Transition Economies
}

\author{
Sanjaya Acharya ${ }^{1, *}$ and Shamshimukhamed Nuriev² \\ ${ }^{1}$ Oxford Policy Management, 30/31 Jitjung Marg, Thapathali Height, Kathmandu, Nepal \\ ${ }^{2}$ Bureau of Research, Ministry of Finance, Republic of Uzbekistan
}

\begin{abstract}
This paper explores the linkages among public investment, growth and poverty in light of the existing theories, evidence and methods for 30 transition economies using the panel data for 1995-2010. Using Least Square Dummy Variable technique, we conclude that public investment is growth enhancing; furthermore, the impact is even higher if associated with foreign direct investment. However, public investment is still not strong enough to reduce poverty, poverty gap and inequality in income distribution. In case of the latter, it has rather worsening impact. But if public current expenditure is spent primarily on educational subsidies, this brings pro-poor growth impact.
\end{abstract}

Keywords: Public investment, Growth, Poverty, Transition economies.

\section{INTRODUCTION}

One of the most important contributions of the "new" growth theory is the insight into the role of fiscal policy in long-run growth. In his seminal contribution, Barro (1990) argues that when the private rate of return to capital is lower than its social rate, optimal allocation calls for further capital accumulation. A vast theoretical literature on endogenous growth underscores the importance of fiscal policy, in the form of public capital flow and stock for economic growth (e.g., Turnovsky, 2000; Agenor, 2008).

An understanding of the impact of public investment on growth is relevant for at least three reasons. First, it has been argued that tight budgets constrain public investment more than current spending because it is easier to cut the former than latter for political and other reasons (Roy, Heuty, and Letouze, 2006). Since the late 1990s, this has led to calls to correct the bias against public investment, most importantly in infrastructure, and create "fiscal space" for funding such investment (Heller, 2005). Underlying this premise is the belief that public investment is productive. Second, although a country's borrowing capacity depends primarily on its macroeconomic policies, ability to collect taxes, and strength of its public financial and debt management systems, the contribution of debt-financed public investment to growth and export also plays a role in external borrowing limits. Finally, fiscal policy has a countercyclical role to play in supporting growth and

*Address of correspondence to this author at the Oxford Policy Management, 30/31 Jitjung Marg, Thapathali Height, Kathmandu, Nepal; Tel: 977-1-4247317; Fax: 977-1-4223149; E-mail: Sanjaya.Acharya@opml.co.uk

JEL Classifications: H32; 132; P34; O43. recovery, which has been recognized during the recent financial crisis.

In general, several channels exist through which public investment can affect growth (see Agénor, 2004). First, crowding-out effects may occur if increases in public investment are financed through higher taxes (which may reduce the net rate of return on private investment, and therefore the incentive to invest) or by borrowing from domestic financial markets, thereby driving up domestic interest rates or leading to greater rationing in the quantity of credit allocated to the private sector. Second, public investment may enhance growth by improving the factor productivity, independently of its effect on factor accumulation (Acharya and Cohen, 2008). Recently, the macroeconomic effect of public investment has renewed the interest of policymakers and development economists as evident from Commission on Growth and Development (2008), Hall (2009), Council of Economic Advisers (2010), Zandi (2011), Woodford (2011), and Congressional Budget Office (2012). Moreover, the UN Millennium Project (2005) has also re-emphasised the need for a "big push" strategy in public investment to help poor countries break out of their poverty trap and meet the MDG challenge.

In line with the backdrop explained above, the objective of this study has three folds. It aims to explore the linkages between public investment, growth and poverty reduction in light of existing theories, evidence and methods. This is particularly important at present, as we are once again witnessing pressure for substantial increases in public investment as a tool to overcome the impact of recent world economic crisis in developing countries, especially with economies in 
transition in the context of slow progress in meeting Millennium Development Goals.

We will examine the relationship between the public investment and growth, between growth and poverty reduction, and the direct relationship between public investment and poverty reduction. Moreover, we also examine the role of private investment particularly that of foreign direct investment (FDI), on growth. Furthermore, the paper examines whether the growth in transition countries has contributed poverty reduction.

The remainder of the paper is organised as follows. Section 2 discusses the theoretical issues on public investment, growth, and poverty reduction. The scenario of transition is the subject matter of Section 3. The sources of data used have been explained in Section 4 followed by study findings and discussions in Section 5. Conclusion and implications are presented in Section 6.

\section{THEORETICAL AND EMPIRICAL ISSUES}

Barro (1990) theorised the linkage between public spending and economic growth by using an endogenous growth model; however, only flow of public expenditure has been taken into account in the model. Recognising this fact, Futagami et al. (1993) adopted Barro's model to reach the same conclusion in another polar case where public services are derived from public capital only. The extension of Barro's model went further when Tsoukis and Miller (2003) assumed the derivation of public services from both public capital and public expenditure flow and concluded that the growth-maximising ratio of public spending over GDP should be equal to the public service's elasticity in aggregate production.

In this paper, we use the model developed by Tsoukis and Miller (2003) with simple modification. In addition to public capital expenditure, public current expenditure and tax rate, we also use technology as the determinant of economic growth. As discussed in the previous section, the effect of FDI on economic growth can be recognised via technology upgrade (Moosa, 2002; and EBRD, 2007) and industrialisation in developing countries (UNCTAD, 1999).

Public--private capital complementarity is also crucial in analysing public investment impact on growth (Durham, 2004 and Cincera M. et al., 2007). Aggregate production function for an economy is of the form:
$\mathrm{Y}=A \cdot f(K, G, N, L)$

where $\mathrm{Y}$ is aggregate output, $\mathrm{K}$ is private capital (human and/or physical), $\mathrm{G}$ is public capital, $\mathrm{N}$ is natural resources, $L$ is the labour force, and $A$ is the level of technology or total-factor productivity. Equation (4) can be approximated by a Cobb Douglas function of the form:

$\mathrm{y}=A \cdot k^{\alpha} \cdot g^{\beta}$

where $y=Y / L$ is output per worker, $k=K / L$ is private capital per worker, and $g=G / L$ is public capital per worker, and the parameters $\alpha$ and $\beta$ represent the elasticity of aggregate output with respect to private and public capital, respectively. Assuming also that the rate of private saving is unaffected by the return to private investment, the long-run or "steady-state" level of output per worker $\left(y^{*}\right)$ is then given by:

$y^{*}=A^{1 / \gamma} \cdot\left(\frac{s_{p}}{\delta_{k}}\right)^{\alpha / \gamma} \cdot\left(\frac{s_{g}}{\delta_{g}}\right)^{\beta / \gamma}$

where $s_{p}$ is the share of private investment in national income, $s_{g}$ is the share of public investment in national income, $\delta_{k}$ and $\delta_{g}$ are the rates of depreciation of private and public capital respectively, and $\gamma=1-\alpha-\beta$, i.e. sum of output elasticities equals one.

Equations (1) to (3) could be extended to include several different types of public capital and investment, each with a potentially different effect on long-run output per worker and economic growth. Equation (6) could also be extended to a more general functional form. In this case, the impact of public investment on economic growth will be more varied and will depend at least on the followings:

- $\quad$ kind of public investment;

- amount of investment

- $\quad$ initial stock of public capital; and

- $\quad$ economic context in which investment occurs

In empirical front, several studies exist on the effects of public investment on economic growth, poverty and inequality, and composite effects on growth and poverty.

\subsection{Effects of Public Investment on Economic Growth}

One of the earliest studies that looked at the impact of public investment on economic growth was by Barro 
(1991) that found a positive but insignificant impact of public investment on economic growth over the period 1960-85. However, Canning and Fay (1993) and Easterly and Rebelo (1993) showed stronger evidence of a positive effect on economic growth from certain types of public investment. The former used panel data of transportation networks -- measured as an aggregate of kilometres of paved roads and railway lines -- and revealed an output elasticity of about 0.10 with relatively high implied rates of return for many developing countries.

Easterly and Rebelo (1993) extended the analysis in two directions, firstly by including investment by public enterprises as well as that by central government, and secondly by distinguishing different public investments by sectors. In contrast with Barro (1991), public investment by central government was found to have a positive and statistically significant effect on economic growth. Moreover, investment in transport and communications had a particularly large and statistically significant effect on economic growth.

Devarajan et al. (1996) challenged this finding by signalling that capital expenditure, if goes in excess, has a negative and statistically significant effect on growth. Pritchett (2000) explains the "white elephant" hypothesis of Devarajan et al. (1996) and signals unproductive public investment in developing countries. However, according to Pritchett (2000), higher public investment - particularly in infrastructure capital such as highways, water systems, sewers, and airports - is likely to bear a complementary relationship with private capital in the production technology that may raise the marginal productivity of capital and thereby "crowd in" private investment.

Under the balanced exogenous growth hypothesis, public spending in the long run does not affect economic growth (King et al., 1991). According to endogenous-growth approach, output follows a stochastic trend; and permanent policy changes have long-term consequences for the growth of output whereas temporary policy changes have long-term consequences for the level of output.

Aschauer (2000) and Milbourne et al. (2003) have tested the predictions of a neo-classical growth model in which public capital as a compliment to private capital, particularly in transport/communication and education, had the largest impacts on growth whereas the effects of investments in agriculture, health, housing and industry were not statistically significant. Likewise, Milbourne et al. (2003) also reinforce that when allowing for possible reverse causation, uncertainty about the size of their estimates increases substantially, especially those translating investment in different sectors to economic growth. In Similar front, using cross-country data for the period 1960-2000, Canning and Bennathan (2000) suggest that the marginal productivity of public capital - measured with electricity-generating capacity (kilowatts), and the length of paved roads -varies considerably across countries.

In spite of these results, two studies - Levine and Renelt (1992) and Sala-i-Martin (1997) -- reported that no measure of public expenditure, including public investment, can be said to have a robust effect on economic growth. Part of the difficulty is that, in all likelihood, the efficiency of public investment - in other words, the impact of investment spending on the size and quality of the public capital stock - varies substantially across countries (Pritchett, 2000). This obscures the underlying relationship between public capital and private sector productivity; therefore, some researchers have looked at the effect of direct measures of public capital and infrastructure on economic growth.

\section{Effects of Public Capital on Productivity}

In terms of the impact of public capital on productivity, Aschauer (1989) showed that public capital in the United States was indeed productive, and that much of the decline in private sector productivity in the country between 1970 and 1985 could be attributed to insufficient public investment and a decline in the public capital stock. A large number of papers followed the work of Aschauer (1989). Gramlich (1994) provides a good empirical review. The quantity index of infrastructure constructed by Calderon and Serven (2004) shows a large, varying and statistically significant impact on GDP.

At the sectoral level, Binswanger et al. (1993) estimated the large and significant impact of irrigation and roads on agricultural productivity in India. Likewise, Mitra et al. (1998) found public infrastructure having a positive, large and statistically significant impact on productivity and technical efficiency (as measured by total factor productivity) in the Indian manufacturing sector.

\section{Effects of Public Investment on Poverty and Inequality}

Some recent studies have focussed on poverty. Gomanee et al. (2003) and Mosley et al. (2004) 
estimated a negative and statistically significant impact of the higher government expenditure on education, agriculture, and housing and amenities (water, sanitation and social security) on poverty, presumably by shifting the distribution of income in favour of the poor.

Some other cross-country/states analyses, for example, Fan et al. (1999) explored agricultural research and development (R\&D), rural roads, rural education and targeted rural development expenditure all having negative and statistically significant effects on rural poverty in India. Among these, spending on agricultural R\&D and rural roads has by far the largest impacts on both growth and poverty reduction. ${ }^{1}$ Datt and Ravallion (2002) emphasised on development spending for the same. Fan et al. (2002) conducted a similar analysis across Chinese provinces. Spending on rural education had the largest impact on poverty, followed by agricultural R\&D and rural roads.

\section{Effects of Economic Growth on Poverty}

The contribution of public investment to growth and poverty reduction has not always been as positive or as significant as one might expect. Despite the development of increasingly sophisticated methods for assessing the desirability of public expenditure during the 1960s and 1970s, large increases in public investment in many developing countries between 1974 and 1982 often yielded few returns (Easterly, 2001). Fedderke and Bogetic (2009) presented five reasons for the contradictory empirical findings: the presence of non-linearity; crowding out effect; endogeneity; an indirect or complementarity effect (rather than a direct productivity effect); and problems of aggregation.

\section{THE SCENARIO OF TRANSITION}

Breakdown of the Soviet Union had significant economic implications for former members of the Union. GDP declined with unprecedented scale during peacetime. The cumulative loss of output and incomes during 1991-2001 was equivalent to about three years of GDP of the former Soviet Union although the distribution of these losses among the affected countries and social groups was, of course, different.

\footnotetext{
${ }^{1}$ For each category of expenditure they calculate the marginal impact of public expenditure. This is obtained by multiplying the elasticity of poverty with respect to public expenditure by the ratio of poverty to government expenditure.
}

Due to the low level of development and slower institutional reforms in Central Asian countries, their transition to a market-based system over the past two decades has been much more difficult than in the European part of the CIS. Economic contraction and consequent negative impact on growth, poverty reduction and employment have become longer and greater in magnitude. During the first half of the 1990s, real GDP of Central Asian countries fell by more than 50 percent while poverty and inequality increased substantially.

In general, the liberalisation of capital account and particularly foreign direct investment (FDI) flows, with varying degrees of intensity, has little impact on employment.

In most Central and Eastern European as well as CIS countries, there have been three or more consecutive years of positive economic growth and the pre-1989 level of GDP has recently restored. However, social improvements have become much slower and more uneven due to the increasing inequality of income distribution and pervasive poverty. In some countries, living standards are rising and poverty levels are falling; however, in the poorer CIS countries, the reversal of the difficulties of the 1990s is still far away. Widespread poverty remains in areas outside the capital cities.

CIS and other countries such as Bulgaria and Romania inherited a relatively large human capital stock from the socialist regime due to the relatively large investments in health and the well-developed and comprehensive system of education. They also established research infrastructure that was more developed and sophisticated than those of market economies on similar development levels. After the regime change, the quality of state financed education deteriorated quickly and a large number of research institutes ceased to exist.

Most of the countries began transformation with extensive hidden unemployment and at least one-tenth of its population below the poverty level (based on a "social minimum" consumption basket). The growth of poverty has not been a consequence of the transition crisis, as it has been growing since the early 1980 due to external indebtedness and mismanagement.

The abundance of existing theories, evidence and methods on the poverty impact of public investment, however, clashes with the reality of policy-making processes in countries with transition, which are often 
characterised by limited technical capacity, unavailability of detailed and reliable data, heavy reliance on external assistance, and political interference which undermine a rational approach to assessing policy alternatives.

At the end of the 20th century the transition from socialism to capitalism was one of the most significant events in the world economy since industrialisation. Transition affected about $25 \%$ of the population of the world and changed the social and political landscape far beyond the countries immediately affected.

\section{DATA AND THE MODEL}

\subsection{The Data}

In 2000 , the IMF listed the following 30 countries as transition economies:

$\begin{array}{ccc}\text { Albania } & \text { Georgia } & \text { Poland } \\ \text { Armenia } & \text { Hungary } & \text { Romania } \\ \text { Azerbaijan } & \text { Latvia } & \text { Russia } \\ \text { Belarus } & \text { Lithuania } & \text { Slovak Republic } \\ \text { Bulgaria } & \text { Kazakhstan } & \text { Slovenia } \\ \text { Cambodia } & \text { Kyrgyz Republic } & \text { Tajikistan } \\ \text { China } & \text { Laos } & \text { Turkmenistan } \\ \text { Croatia } & \text { Republic of Macedonia } & \text { Ukraine } \\ \text { Czech Republic } & \text { Moldova } & \text { Uzbekistan } \\ \text { Estonia } & \text { Mongolia } & \text { Vietnam }\end{array}$

In addition, in 2002 the World Bank (WB) included Bosnia and Herzegovina, and the Federal Republic of Yugoslavia (later Serbia and Montenegro) and in 2009 Kosovo in transition economies. But these countries have been omitted from our sample because of the unavailability of data. The data used in this study are obtained from the IMF's World Economic Outlook (WEO), World Development Indicators (WDI) of the WB and partially from UNCTAD, UNDP and ADB.

\subsection{Model Specification}

The following equation is estimated using the LeastSquares Dummy Variable (LSDV) ${ }^{2}$ regression model:

\footnotetext{
${ }^{2}$ We have followed LSDV technique of regression because of two reasons. First, our objective is to observe whether the impacts are different in specific
}

$$
\begin{aligned}
\text { Growth }_{i t}= & \beta_{0}+\beta_{1} \text { Pubinv }_{i t}+\beta_{2} \text { Pubcur }_{i t}+\beta_{3} \text { Prinv }_{i t}+\beta_{4} \text { Fdi }_{i t} \\
& +\beta_{5} \text { Tax }_{i t}+\alpha_{1} \text { Dm } 1+\alpha_{2} \text { Dm } 2+\gamma_{1} \text { Dm } 3+\gamma_{2} \text { Dm } 4+\varepsilon_{i t}
\end{aligned}
$$

where $i=1,2, \ldots, N$ (number of countries) and $t=1995$, $1996, \ldots, 2010$, Growth is the five-year forward moving average of GDP growth rate for country i; Pubinv, Pubcur, Prinv, Fdi and Tax are all the respective ratios of annual public capital expenditures, public current expenditures, private domestic capital flow, FDI, and total tax revenue with GDP; $D m 1$ and $D m 2$ are the country dummy variables ( 8 transition countries that joined the EU, and 4 central Asian countries, respectively); $D m 3$ and $D m 4$ are period dummy variables (1995-1999 and 2000-2006, respectively); $\varepsilon_{i t}$ is the error term.

The model is used to estimate equations with a fiveyear forward lag structure, i.e. explanatory variables in period $t$ would have an effect on growth from period $t+1$ through $t+5$. There are three benefits associated with this approach. First, it implies that it takes time before the impacts of government expenditure and FDI on economic growth are recognised. Second, it reduces the possibility of reverse causality, i.e. government expenditures and FDI might change subject to the economic performance of a country, which is indicated by its economic growth rate. Finally, the fluctuation of short-term growth, which is a result of changes in public investment and FDI, is reduced (Devarajan et al., 1996).

The following equation is expected to capture the overall effect of all the factors mentioned on poverty reduction:

$$
\begin{aligned}
& \text { Pind }_{i(t+1)}=\beta_{0}+\beta_{1} \text { Pubinv }_{i t}+\beta_{2} \text { Growth }_{i t}+\beta_{3} \operatorname{Inf}_{i t} \\
& +\beta_{4} U_{n p l}+\beta_{5} D m 1+\beta_{6} D m 2+\alpha_{1} P_{u b c u r} \\
& +\gamma_{1} \text { Pubedu }_{i t}+\gamma_{2} \text { Pubhth }_{i t}+\mu_{1} \text { Gsav }_{i t}+\varepsilon_{i t}
\end{aligned}
$$

where $i=1,2, \ldots, N$ (number of countries) and $t=1995$, 1996, ... 2010; Pindx is one of the poverty indices for country $i$ in time $t+1$; Inf and Unpl are the inflation and unemployment rate at time $\mathrm{t}$, respectively; Pubedu, Pubhth and Gsav are the ratios of public expenditures on education and health, and gross savings to GDP, respectively; $\varepsilon_{i t}$ is the error term. Other variables follow from equation (4).

blocks of transition economies such as countries that accessed European Union, central Asian transition countries. Likewise, differential impacts in different phases of transition -- first phase 1995-1999 and second phase 20002006 -- have also been captured by this technique. 
Within this framework, we investigated the dynamics of public and private investment (including FDI) and their impacts on growth, poverty and distribution. $^{3}$

\subsection{Characteristics of Transition Economies}

The average growth rate of these transition economies during 1995-2010 was around five per cent - the maximum rate was experienced by Azerbaijan (more than 10\%) whereas the growth rate of Ukraine remained minimal (about 1.5\%). Likewise, the rate of public capital formation (expressed as a percentage of GDP) varied widely - from less than 1.5 per cent in Armenia upto approximately 27 per cent in China (See Appendix Table A1).

High public current expenditure - as a legacy of socialist economy - still remained high (more than 15\%) during transition. In South East Asian transition economies such as Vietnam and Lao this was less than seven per cent of GDP but in some East European countries such as Latvia, Czech Republic, Lithuania, Ukraine, Croatia, Hungary, and Slovak Republic, this was more than one-fifth of their GDP. Likewise the rate of inflation was also rampant in some countries -more than 100 per cent in Belarus and Turkmenistan, followed by Bulgaria and Tajikistan (in the range of $70 \%$ ); and Azerbaijan, Ukraine, Uzbekistan (in the range of $40-60 \%)$. In an average, the rate of inflation was hovering around 27 per cent among transition economies during 1995-2010.

Unemployment rate was significantly high in Macedonia (34\%) followed by Armenia (32\%); however, in rest of the cases it was less than 16 per cent and average unemployment rate remained approximately 11 per cent. The unemployment rate was significantly lower in Asian transition economies (less than 4 percent) as compared to their European counterparts.

\footnotetext{
${ }^{3}$ The models proposed in this study have fully considered the possibility of endogeneity problem. All three possibilities of the existence of endogeneity omitted variable biasness, measurement errors, and simultaneity - have been taken into account. Although the possibility of endogeneity problem is relatively less in panel data than in purely time-series data, we have taken majority of the endogenous variables as their ratios with GDP to address the measurement error. Therefore, the measurement errors in the exogenous block of the variables have very limited possibility of creating endogeneity problem. Furthermore, our exogenous block of the variables does have a lot of policy variables to observe their impacts on the corresponding endogenous variable that signals the orientation of the paper towards developing logical policy prescriptions. The possibility of reverse causality was in case of first model (equation 4); this problem has been addressed by talking the five-year moving average growth rate of the GDP (the dependent variable). Devarajan et al. (1996) have also followed similar approach in addressing the endogeneity problem of this nature.
}

Private investment remained very significant in some transition economies - examples include Vietnam (31\%) and Estonia (30\%) - and less significant in some other countries such as Tajikistan $(6 \%)$ and Cambodia (10\%). In average, the private investment was approximately one-fifth of their GDP. However, FDI inflow was about 5.5 per cent of GDP. Azerbaijan and Hungary had relatively high FDI inflow - 18.6 and 10.7 per cent of GDP, respectively -whereas other countries had relatively small FDI inflow.

In average, transition economies were collecting taxes approximately 15.6 per cent of their GDP; however, in some countries tax collection was relatively higher; those collecting more than one fifth of their GDP were Azerbaijan (28\%), Croatia (23\%), Hungary (22\%), Slovenia (20\%), and Uzbekistan (24\%).

Appendix Table A2 presents pairwise correlation matrix of them to detect whether any multi-collinearity exists among the variables used in the model. Although perfect collinearity does not exist among variables used in the models, minor degree of collinearity might be present between some variables. For example, public current expenditure is collinear at some degree with public education expenditure and public health expenditure; therefore, we have not used these two variables along with public current expenditure. The public current expenditure shows mainly going to public health and education expenditure in the transition economies. Likewise, human development index does also reveal some degree of collinearity with public current expenditure and the literacy rate; therefore, these variables have not appeared together with human development index in the endogenous block of the variables in the same model.

\section{FINDINGS AND DISCUSSIONS}

\subsection{Public Investment and Growth}

The results of Ordinary Least Square (OLS) regression are shown in column 1; while columns 2 and 3 show the results of Least-Squares Dummy Variable (LSDV) regression with cross-countries and period dummy, respectively (Table 1). In Table 2, columns 4-7 check the robustness of the estimation by introducing two additional variables: rate of inflation and unemployment rate.

Both public capital and public non-capital expenditures have significant impacts on GDP growth rate measured as five-year forward moving average. 
An increase in public capital expenditure leads to higher economic growth rate while the effect caused by a higher public non-capital expenditure is reverse. A unit increase in this public current expenditure would in turn reduce a growth rate by approximately 0.22 percentage points. This effect is expected because public capital plays an important role in enhancing the productivity of private capital; an increase in public noncapital expenditure would create only a negative effect, as more tax is needed to finance this increase in noncapital expenditure (Barro, 1990); see also Gupta et al. (2002).

The estimation also shows a positive and statistically significant relationship between the GDP growth rate measured as five-year forward moving average and the ratio of FDI to GDP. The coefficients of FDI range from 0.061 to 0.086 in different models. It is noted that the coefficient of public investment to GDP ratio is larger than the coefficient of FDI to GDP ratio. This effect is expected as mentioned above even if there is good investment climate the FDI inflow in the transition economy is rather slow.
While total tax ratio is found to be positively associated with GDP growth rate, private investment is found to have no significant contribution to the GDP growth rate; this has been over-shadowed by the strong need of public investment.

As expected, high rate of inflation is detrimental to GDP growth rate (Table 2, columns 4 and 5 ) but the association is insignificant. However, the rate of unemployment does not follow the expected relationship with the growth rate in transition economies (columns 6 and 7 ). Most likely this is due to the more capital intensive mode of production along with FDI inflow and consequent rise in unemployment but with relatively higher GDP growth performance.

\subsection{Public Investment and Poverty Reduction}

The welfare approach to poverty alleviation typically used by economists assumes that individuals know what is best for them and that monetary measure of consumption or income can serve as an indicator of well-being. Using this approach, poverty line is defined

Table 1: Impact of Public Investment and other Variables on Growth

Dependent variable: five-year forward moving average of GDP growth rate

\begin{tabular}{|c|c|c|c|}
\hline Variable & (1) OLS & (2) LSDV & (3) LSDV \\
\hline Constant & $\begin{array}{c}7.947 \\
(11.799)^{\star \star \star}\end{array}$ & $\begin{array}{c}7.299 \\
(9.416)^{\star * *}\end{array}$ & $\begin{array}{c}4.772 \\
(6.943)^{\star * *}\end{array}$ \\
\hline Pubinv & $\begin{array}{c}0.158 \\
(4.907)^{\star * *}\end{array}$ & $\begin{array}{c}0.134 \\
(3.653)^{\star * *}\end{array}$ & $\begin{array}{c}0.201 \\
(6.904)^{\star \star *}\end{array}$ \\
\hline Pubcur & $\begin{array}{c}-0.240 \\
(8.439)^{\star \star \star}\end{array}$ & $\begin{array}{c}-0.194 \\
(5.004)^{\star * *}\end{array}$ & $\begin{array}{c}-0.219 \\
(8.565)^{\star \star *}\end{array}$ \\
\hline Prinv & $\begin{array}{l}-0.030 \\
(1.372)\end{array}$ & $\begin{array}{l}-0.020 \\
(0.832)\end{array}$ & $\begin{array}{l}-0.004 \\
(0.190)\end{array}$ \\
\hline FDI & $\begin{array}{c}0.061 \\
(2.444)^{\star \star}\end{array}$ & $\begin{array}{c}0.064 \\
(2.525)^{\star *}\end{array}$ & $\begin{array}{c}0.086 \\
(3.814)^{\star \star \star}\end{array}$ \\
\hline TAX & $\begin{array}{c}0.042 \\
(1.432)\end{array}$ & $\begin{array}{c}0.035 \\
(1.155) \\
\end{array}$ & $\begin{array}{c}0.049 \\
(1.868)^{\star}\end{array}$ \\
\hline Dm1 & - & $\begin{array}{c}-0.652 \\
(1.661)^{\star}\end{array}$ & - \\
\hline Dm2 & - & $\begin{array}{c}0.558 \\
(0.984)\end{array}$ & - \\
\hline Dm3 & - & - & $\begin{array}{c}1.939 \\
(5.874)^{\star \star \star}\end{array}$ \\
\hline Dm4 & - & - & $\begin{array}{c}3.332 \\
(10.737)^{\star \star \star}\end{array}$ \\
\hline Observations & 459 & 459 & 459 \\
\hline $\mathbf{R 2}$ & 0.222971 & 0.228809 & 0.381163 \\
\hline
\end{tabular}

Absolute value of $t$ statistics in parentheses.

*significant at $10 \%$; **significant at $5 \%$; ${ }^{* *}$ significant at $1 \%$. 
Table 2: Growth Model: Robustness Checking

Dependent variable: five-year forward moving average of GDP growth rate

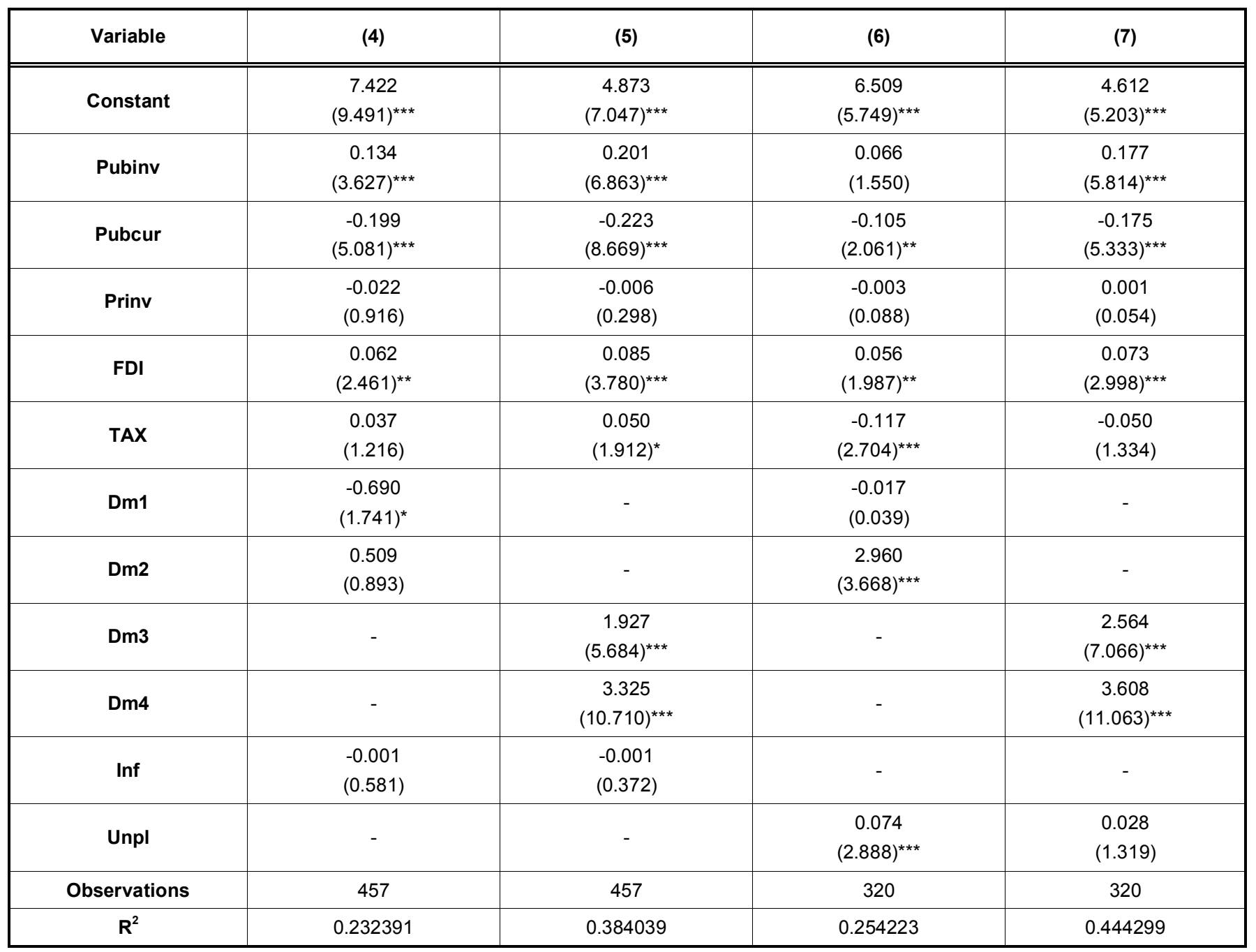

Note: (i) Absolute value of $t$ statistics in parentheses.

(ii) Albania, Armenia, Azerbaijan, Belarus, Cambodia, Croatia, Kyrgyz Republic, Lao DPR, Moldovia, Tajikistan, Turkeministan, and Uzbekistan do not have fuller data set on unemployment. Because of the missing data of these countries for several years, the number of observations drastically declined in model 6 and 7 .

(iii) *significant at $10 \%$; ${ }^{* *}$ significant at $5 \%$; ${ }^{* * *}$ significant at $1 \%$.

as a level of income, and all those under that line are considered poor. The welfare approach measures the standard of living with individual consumption, generally measured by using expenditure data, and wherever possible including consumption from own production as well. Where expenditure data are not available, income can be taken as the proxy for consumption.

Three measures of poverty are usually used:

- $\quad$ Poverty head count index $(\mathrm{HCl})$, which measures the abundance of poverty;

- Poverty gap index (PGI), which measures the depth of poverty; and
- $\quad$ Foster-Greer-Thorbecke (FGT) index that measures the sternness of poverty.

When analysing poverty in developing countries, and countries with transition economies in particular, unfortunately the required data are often poor that these measures are difficult to calculate reliably. Therefore, in this paper we use only two of these indicators: Poverty head count ratio and Poverty gap at $\$ 2$ a day on a purchasing power parity (PPP), as well as Human Development Index (HDI) and Gini coefficient (as inequality is also regarded as one facet of overall poverty scenario). Tables 3-6 present the results from estimation of various versions of equation 5 (Section 4.2). 
1. The Head Count Index (HCl). The simplest measure of poverty, in principle, is the head count index, which measures the number of people with income below a poverty line and considers them equally poor. In our sample the $\mathrm{HCl}$ range from 0.02 per cent of population (Slovenia in 2002) to 83.65 per cent of population (Tajikistan in 1998). In practice, these data are often not available, or are not available in a format comparable across countries. However, based on the extent of availability, Table 3 presents the results of the model which examines the relationship between public investment and growth with $\mathrm{HCl}$.

The impact of public investment and growth on poverty along with other explanatory variables are shown in Column 1 using LSDV regression. The significant dummy variables indicate that both periods of time have significant trends in poverty head count ratio over the years. A closer look on Columns 2-4 in Table 3 reveals some interesting facts. Public current expenditures (Column 2) shows strong impact on poverty reduction. It is because the current expenditures are associated with subsidies often targeted to poor population; therefore, possess important role in poverty reduction although it causes overall growth prospect of the economy decline (Table 2).

A major part of public current expenditures go on health and education related subsidies. Therefore, we have used two additional variables - public health expenditures and public education expenditures - in third model (Table 3, Column 3). Between them, the public education expenditures have been proved important in poverty reduction. As the economy has moved towards skilled economy, the growth accrued has also caused poverty reduction.

Table 3: Impact of Public Investment and Growth on $\mathrm{HCI}$

Dependent variable: one-year forward moving of $\mathrm{HCl}$

\begin{tabular}{|c|c|c|c|c|c|}
\hline Variable & 1 & 2 & 3 & 4 & 5 \\
\hline Constant & $\begin{array}{c}14.536 \\
(5.467)^{\star * *}\end{array}$ & $\begin{array}{c}28.465 \\
(5.678)^{\star \star \star}\end{array}$ & $\begin{array}{c}38.804 \\
(6.139)^{\star \star \star}\end{array}$ & $\begin{array}{c}30.913 \\
(7.774)^{\star \star \star}\end{array}$ & $\begin{array}{c}12.357 \\
(4.325)^{\star \star \star}\end{array}$ \\
\hline Pubinv & $\begin{array}{l}-0.056 \\
(0.210)\end{array}$ & $\begin{array}{c}0.193 \\
(0.713)\end{array}$ & $\begin{array}{c}0.401 \\
(1.092)\end{array}$ & $\begin{array}{c}0.192 \\
(0.761)\end{array}$ & $\begin{array}{c}0.804 \\
(1.581)\end{array}$ \\
\hline Growth & $\begin{array}{l}-0.022 \\
(0.101) \\
\end{array}$ & $\begin{array}{c}-0.272 \\
(1.186)\end{array}$ & $\begin{array}{c}-0.888 \\
(3.404)^{\star * *}\end{array}$ & $\begin{array}{c}0.410 \\
(2.104)^{\star *}\end{array}$ & $\begin{array}{c}0.368 \\
(1.243) \\
\end{array}$ \\
\hline Inf & $\begin{array}{l}-0.019 \\
(0.652)\end{array}$ & $\begin{array}{c}-0.034 \\
(1.168)\end{array}$ & $\begin{array}{c}-0.108 \\
(1.639)\end{array}$ & $\begin{array}{c}0.003 \\
(0.095)\end{array}$ & $\begin{array}{l}-0.024 \\
(0.804)\end{array}$ \\
\hline Unpl & $\begin{array}{l}-0.073 \\
(0.551)\end{array}$ & $\begin{array}{c}-0.032 \\
(0.244)\end{array}$ & $\begin{array}{c}0.051 \\
(0.237)\end{array}$ & $\begin{array}{c}-0.218 \\
(1.718)^{\star *}\end{array}$ & $\begin{array}{l}-0.121 \\
(0.902)\end{array}$ \\
\hline Dm3 & $\begin{array}{c}-12.214 \\
(5.758)^{\star * *}\end{array}$ & $\begin{array}{c}-9.081 \\
(3.984)^{\star * *}\end{array}$ & $\begin{array}{c}-6.270 \\
(2.419)^{\star *}\end{array}$ & $\begin{array}{c}-14.129 \\
(7.042)^{\star * *}\end{array}$ & $\begin{array}{c}-12.154 \\
(5.777)^{\star \star \star}\end{array}$ \\
\hline Pubcur & - & $\begin{array}{c}-0.845 \\
(3.244)^{\star * *}\end{array}$ & - & - & - \\
\hline Pubhth & - & - & $\begin{array}{c}1.043 \\
(1.173)\end{array}$ & - & - \\
\hline Pubedu & - & - & $\begin{array}{c}-6.999 \\
(6.230)^{\star \star \star}\end{array}$ & - & - \\
\hline Gsav & - & - & - & $\begin{array}{c}-0.870 \\
(5.259)^{\star \star \star}\end{array}$ & - \\
\hline Pubinv*Growth & - & - & - & - & $\begin{array}{c}-0.108 \\
(1.980)^{\star \star}\end{array}$ \\
\hline
\end{tabular}


The gross savings are also found to have been contributing to poverty reduction because of the rise in overall investment in the economy. Unemployment rate also rises in the economy possibly due to the private sector's orientation towards capital-intensive mode of production. However, the growth of unemployment is moving along with poverty reduction as a likely impact of higher factor productivity. Column 5 includes the interaction term between public capital expenditures and growth.

The interaction term being negative suggests that public investment and growth do jointly reduce poverty in transition economies. It means if public investment is growth enhancing, it possesses the strength of poverty reduction, otherwise not.

Among the group of transition countries in this study, Azerbaijan, Belarus, Cambodia, Chez Republic,
Georgia, Kazakhstan, Poland, Slovenia, Turkmenistan, and Uzbekistan do not have data on public investment in health sector. Likewise, share of public investment in education sector is not available for 1995. Furthermore, for Albania, Armenia, Azerbaijan, Belarus, Bulgaria, Cambodia, China, Croatia, Czech Republic, Estonia, Georgia, and Hungary, public investment in education is not available for 2010. Therefore, once these two variables are included in the model and some others are removed, the number of observations drastically declines. This has caused the sharp decline in the number of observations in model 3 (Table 2). Similar is the case in Tables 4-6 as well.

Comparison of the results presented in Tables 2 and 3 reveals an adequate strength of public investment in raising the growth rate of the transition economy but still not enough to poverty reduction.

Table 4: Impact of Public Investment and Growth on PGI

Dependent variable: one-year forward moving of PGI

\begin{tabular}{|c|c|c|c|c|c|}
\hline Variable & 1 & 2 & 3 & 4 & 5 \\
\hline Constant & $\begin{array}{c}4.150 \\
(4.806)^{\star * *}\end{array}$ & $\begin{array}{c}7.007 \\
(4.215)^{\star \star *}\end{array}$ & $\begin{array}{c}18.304 \\
(4.154)^{\star \star \star *}\end{array}$ & $\begin{array}{c}7.367 \\
(5.813)^{\star \star \star}\end{array}$ & $\begin{array}{c}3.096 \\
(3.206)^{\star \star \star \star}\end{array}$ \\
\hline Pubinv & $\begin{array}{l}-0.013 \\
(0.159)\end{array}$ & $\begin{array}{c}0.029 \\
(0.348)\end{array}$ & $\begin{array}{c}0.603 \\
(1.292)\end{array}$ & $\begin{array}{c}0.091 \\
(1.076)\end{array}$ & $\begin{array}{c}0.318 \\
(1.958)^{*}\end{array}$ \\
\hline Growth & $\begin{array}{c}0.001 \\
(0.024)\end{array}$ & $\begin{array}{l}-0.037 \\
(0.603)\end{array}$ & $\begin{array}{c}-0.986 \\
(3.517)^{\star \star \star}\end{array}$ & $\begin{array}{c}0.075 \\
(1.216)\end{array}$ & $\begin{array}{c}0.150 \\
(1.739)\end{array}$ \\
\hline Inf & $\begin{array}{l}-0.003 \\
(0.702)\end{array}$ & $\begin{array}{c}-0.004 \\
(0.936)\end{array}$ & $\begin{array}{l}-0.117 \\
(1.748)\end{array}$ & $\begin{array}{l}-0.003 \\
(0.583)\end{array}$ & $\begin{array}{c}-0.002 \\
(0.486)\end{array}$ \\
\hline Unpl & $\begin{array}{l}-0.006 \\
(0.118) \\
\end{array}$ & $\begin{array}{c}0.004 \\
(0.089)\end{array}$ & $\begin{array}{c}0.194 \\
(1.015)\end{array}$ & $\begin{array}{l}-0.043 \\
(0.910)\end{array}$ & $\begin{array}{c}-0.017 \\
(0.366)\end{array}$ \\
\hline Dm3 & $\begin{array}{c}-3.733 \\
(5.300)^{\star * *}\end{array}$ & $\begin{array}{c}-3.045 \\
(3.907)^{\star \star *}\end{array}$ & $\begin{array}{c}-5.918 \\
(2.317)^{\star \star}\end{array}$ & $\begin{array}{c}-3.873 \\
(5.609)^{\star * *}\end{array}$ & $\begin{array}{c}-3.589 \\
(5.124)^{\star \star \star \star}\end{array}$ \\
\hline Dm4 & $\begin{array}{c}15.762 \\
(8.685)^{* * *}\end{array}$ & $\begin{array}{c}14.506 \\
(7.599)^{\star * *}\end{array}$ & $\begin{array}{c}23.465 \\
(3.278)^{\star * *}\end{array}$ & $\begin{array}{c}16.159 \\
(9.080)^{\star * *}\end{array}$ & $\begin{array}{c}16.038 \\
(8.902)^{\star \star \star}\end{array}$ \\
\hline Pubcur & - & $\begin{array}{c}-0.179 \\
(2.007)^{\star \star}\end{array}$ & - & - & - \\
\hline Pubhth & - & - & $\begin{array}{c}1.104 \\
(1.237)\end{array}$ & - & - \\
\hline Pubedu & - & - & $\begin{array}{c}-7.013 \\
(6.362)^{\star \star *}\end{array}$ & - & - \\
\hline Gsav & - & - & - & $\begin{array}{c}-0.169 \\
(3.406)^{\star \star \star}\end{array}$ & - \\
\hline Pubinv*Growth & - & - & - & - & $\begin{array}{c}-0.037 \\
(2.355)^{\star *}\end{array}$ \\
\hline Observations & 246 & 246 & 130 & 246 & 246 \\
\hline $\mathbf{R 2}$ & 0.514971 & 0.523040 & 0.594237 & 0.537510 & 0.526013 \\
\hline
\end{tabular}

Absolute value of $t$ statistics in parentheses.

${ }^{*}$ significant at $10 \%$; ${ }^{* *}$ significant at $5 \%$; ${ }^{* *}$ significant at $1 \%$. 
The key weakness in this measure is that it only measures changes of income that cross the poverty line and ignores shifts below the poverty line. If a poor person becomes poorer, this is not reflected in the head count index.

2. The Poverty Gap Index alleviates some of the problem mentioned above by measuring the aggregate amount of poverty relative to the poverty line. The poverty gap represents the required transfer of income to the poor that would be necessary to bring the poor out of the poverty line. The poverty gap index is simply the average poverty gap across the entire population.

In case of PGI empirical results (Table 4) are quite similar to that of $\mathrm{HCl}$. It is interesting to note that additional variables - public current expenditures, gross savings and expenditures on education - show negative significant coefficients. These results carry an important message that public current expenditures, more importantly, public education expenditures, is not only strong in reducing head count poverty index (Table 3) but also strong in reducing the poverty gap (Table 4). Furthermore, gross savings is also supportive to reduce poverty gap. Similar to the impact on head count ratio, the interaction between public investment and growth reduces the poverty gap in both periods of transition (Table 4).

3. The Human Development Index was developed and introduced as a new way of measuring development by combining indicators of life expectancy, educational attainment and income into a composite human development index, the HDI. This index sets a minimum and a maximum limits for each dimension, called goalposts, and then shows where each country stands in relation to these goalposts, expressed as a value between 0 and 1 . The higher is the index, the better is the human development condition of the country.

Table 5: Impact of Public Investment and Growth on HDI

Dependent variable: one-year forward moving of HDI

\begin{tabular}{|c|c|c|c|c|c|}
\hline Variable & 1 & 2 & 3 & 4 & 5 \\
\hline Constant & $\begin{array}{c}0.719 \\
(102.754)^{\star \star \star}\end{array}$ & $\begin{array}{c}0.707 \\
(49.674)^{\star * *}\end{array}$ & $\begin{array}{c}0.733 \\
(44.277)^{\star * *}\end{array}$ & $\begin{array}{c}0.666 \\
(62.603)^{\star * *}\end{array}$ & $\begin{array}{c}0.732 \\
(98.530)^{* * *}\end{array}$ \\
\hline Pubinv & $\begin{array}{c}0.003 \\
(4.481)^{\star \star \star}\end{array}$ & $\begin{array}{c}0.003 \\
(3.877)^{\star \star \star}\end{array}$ & $\begin{array}{c}7.390 \\
(0.094)\end{array}$ & $\begin{array}{c}0.001 \\
(1.659)^{*}\end{array}$ & $\begin{array}{c}-0.003 \\
(1.935)^{\star}\end{array}$ \\
\hline Growth & $\begin{array}{l}-0.001 \\
(0.846)\end{array}$ & $\begin{array}{l}-0.004 \\
(0.593)\end{array}$ & $\begin{array}{c}0.001 \\
(0.502)\end{array}$ & $\begin{array}{c}-0.001 \\
(2.042)^{* *}\end{array}$ & $\begin{array}{c}-0.003 \\
(3.269)^{\star * *}\end{array}$ \\
\hline Inf & $\begin{array}{l}-4.780 \\
(1.088)\end{array}$ & $\begin{array}{l}-4.310 \\
(0.975)\end{array}$ & $\begin{array}{c}-0.001 \\
(2.353)^{\star *}\end{array}$ & $\begin{array}{l}-4.380 \\
(1.064) \\
\end{array}$ & $\begin{array}{l}-4.980 \\
(1.165) \\
\end{array}$ \\
\hline Unpl & $\begin{array}{c}-0.001 \\
(2.072)^{\star *}\end{array}$ & $\begin{array}{c}-0.001 \\
(2.155)^{\star *}\end{array}$ & $\begin{array}{c}-0.001 \\
(1.720)^{*}\end{array}$ & $\begin{array}{l}-0.001 \\
(0.405)\end{array}$ & $\begin{array}{l}-0.001 \\
(1.542)\end{array}$ \\
\hline Dm3 & $\begin{array}{c}0.105 \\
(18.462)^{\star * *}\end{array}$ & $\begin{array}{c}0.102 \\
(15.893)^{\star * *}\end{array}$ & $\begin{array}{c}0.089 \\
(13.462)^{\star * *}\end{array}$ & $\begin{array}{c}0.104 \\
(19.537)^{\star * *}\end{array}$ & $\begin{array}{c}0.103 \\
(18.558)^{\star * *}\end{array}$ \\
\hline Dm4 & $\begin{array}{c}-0.185 \\
(15.488)^{\star * *}\end{array}$ & $\begin{array}{c}-0.179 \\
(13.153)^{\star \star *}\end{array}$ & $\begin{array}{c}-0.184 \\
(11.034)^{\star * *}\end{array}$ & $\begin{array}{c}-0.184 \\
(16.059)^{\star * *}\end{array}$ & $\begin{array}{c}-0.192 \\
(16.388)^{\star \star * *}\end{array}$ \\
\hline Pubcur & - & $\begin{array}{c}0.001 \\
(0.940)\end{array}$ & - & - & - \\
\hline Pubhth & - & - & $\begin{array}{c}0.021 \\
(9.254)^{* * *}\end{array}$ & - & - \\
\hline Pubedu & - & - & $\begin{array}{c}0.023 \\
(8.912)^{\star \star \star *}\end{array}$ & - & - \\
\hline Gsav & - & - & - & $\begin{array}{c}0.003 \\
(6.334)^{\star \star *}\end{array}$ & - \\
\hline Pubinv*Growth & - & - & - & - & $\begin{array}{c}0.001 \\
(4.376)^{\star \star \star}\end{array}$ \\
\hline Observations & 315 & 315 & 214 & 313 & 315 \\
\hline $\mathbf{R 2}$ & 0.744966 & 0.745699 & 0.830399 & 0.769461 & 0.759941 \\
\hline
\end{tabular}

Absolute value of $t$ statistics in parentheses.

*significant at $10 \%$; ${ }^{* *}$ significant at $5 \%$; ${ }^{* *}$ significant at $1 \%$. 
As expected, in all cases public investment is found to be positively contributing to the improvement of human development index. Moreover, the rate of inflation and unemployment do have negative impact on human development index.

In the first column of the LSDV regressions (Table 5) we can see the insignificant negative impact of growth rate on HDI. But this is due to the model specification biasness (one reason of endogeneity) because as new variables were introduced, this problem vanished and the relationship established (Columns 4 and 5). Public investment, inflation and unemployment show the expected impact. Public investment positively and significantly affects HDI. Columns 2-5 examine the robustness of the estimation by introducing additional variables: public current expenditures - public expenditures on education and health, and gross savings. All these variables show significant positive effect on HDI. Because of the colinearity problem of public investment with health and education expenditures, the former became insignificant in model 3.

The interaction term in model 5 suggests that public investment and growth support each other to speed-up improvement on human development in transition countries.

4. The Gini coefficient is often used as an indicator of the relative equality of income distribution in a given country. This coefficient measures how far a country's income distribution pattern is deviated from perfect equality. A coefficient of zero would indicate perfect

Table 6: Impact of Public Investment and Growth on Gini Coefficient

Dependent variable: one-year forward moving of Gini coefficient

\begin{tabular}{|c|c|c|c|c|c|}
\hline Variable & 1 & 2 & 3 & 4 & 5 \\
\hline Constant & $\begin{array}{c}31.968 \\
(47.944)^{\star * *}\end{array}$ & $\begin{array}{c}33.327 \\
(25.065)^{\star * *}\end{array}$ & $\begin{array}{c}39.114 \\
(23.093)^{\star * *}\end{array}$ & $\begin{array}{c}31.417 \\
(29.450)^{* * *}\end{array}$ & $\begin{array}{c}32.721 \\
(43.586)^{\star \star \star}\end{array}$ \\
\hline Pubinv & $\begin{array}{c}0.096 \\
(1.764)^{*}\end{array}$ & $\begin{array}{c}0.119 \\
(2.058)^{\star *}\end{array}$ & $\begin{array}{l}-0.106 \\
(1.339)\end{array}$ & $\begin{array}{c}0.034 \\
(0.558)\end{array}$ & $\begin{array}{l}-0.033 \\
(0.277)\end{array}$ \\
\hline Growth & $\begin{array}{c}0.032 \\
(0.658)\end{array}$ & $\begin{array}{c}0.014 \\
(0.278)\end{array}$ & $\begin{array}{c}-0.101 \\
(1.904)^{\star}\end{array}$ & $\begin{array}{l}-0.013 \\
(0.246)\end{array}$ & $\begin{array}{l}-0.039 \\
(0.552)\end{array}$ \\
\hline Inf & $\begin{array}{l}-0.005 \\
(1.156)\end{array}$ & $\begin{array}{l}-0.005 \\
(1.285)\end{array}$ & $\begin{array}{l}-0.020 \\
(1.043)\end{array}$ & $\begin{array}{l}-0.004 \\
(0.861)\end{array}$ & $\begin{array}{l}-0.004 \\
(0.888)\end{array}$ \\
\hline Unpl & $\begin{array}{c}0.150 \\
(3.892)^{\star * *}\end{array}$ & $\begin{array}{c}0.155 \\
(4.011)^{\star * *}\end{array}$ & $\begin{array}{l}-0.020 \\
(0.354)\end{array}$ & $\begin{array}{c}0.148 \\
(3.615)^{\star \star \star}\end{array}$ & $\begin{array}{c}0.136 \\
(3.423)^{\star * *}\end{array}$ \\
\hline Dm3 & $\begin{array}{c}-1.637 \\
(2.972)^{\star * *}\end{array}$ & $\begin{array}{c}-1.306 \\
(2.113)^{\star \star}\end{array}$ & $\begin{array}{c}0.861 \\
(1.264)\end{array}$ & $\begin{array}{c}-1.894 \\
(3.343)^{\star * *}\end{array}$ & $\begin{array}{c}-2.007 \\
(3.556)^{\star * *}\end{array}$ \\
\hline Dm4 & $\begin{array}{c}4.848 \\
(4.3730)^{* * *}\end{array}$ & $\begin{array}{c}4.170 \\
(3.340)^{* * *}\end{array}$ & $\begin{array}{c}3.906 \\
(2.381)^{\star \star}\end{array}$ & $\begin{array}{c}5.053 \\
(4.353)^{\star * *}\end{array}$ & $\begin{array}{c}4.857 \\
(4.272)^{\star * *}\end{array}$ \\
\hline Pubcur & - & $\begin{array}{l}-0.087 \\
(1.181)\end{array}$ & - & - & - \\
\hline Pubhth & - & - & $\begin{array}{c}0.644 \\
(2.650)^{\star * *}\end{array}$ & - & - \\
\hline Pubedu & - & - & $\begin{array}{c}-2.062 \\
(7.974)^{\star * *}\end{array}$ & - & - \\
\hline Gsav & - & - & - & $\begin{array}{c}0.048 \\
(1.194)\end{array}$ & - \\
\hline Pubinv*Growth & - & - & - & - & $\begin{array}{c}0.012 \\
(0.936)\end{array}$ \\
\hline Observations & 307 & 307 & 207 & 304 & 306 \\
\hline R2 & 0.204971 & 0.208662 & 0.342470 & 0.194358 & 0.192706 \\
\hline
\end{tabular}


equality, while a coefficient of 1 would indicate perfect inequality.

Similar to that of non-supportive role of public investment to reduce poverty, poverty gap and to improve human development index, it is also not supporting inequality reduction to the transition economies so far (Table 6). The first two regressions (Column 1 and 2) show even worsening inequality pattern due to public investment. But if there is growing public expenditures on education, then the public investment became supportive to inequality reduction (Column 3).

Regression on inequality, however, explores two important findings. First, rate of unemployment is very big obstacle in reducing inequality as Columns 1, 2, 4 and 5 show their strong positive association. Second, the interaction between growth and public investment alone is not sufficient to reduce inequality in transition economies although the interaction between them was very much important in reducing poverty head count rate, poverty gap and improving human development index (Tables 3, 4 and 5).

The resulted mentioned in Tables 1 to 6 required the test on stationarity to confirm whether the results suffer from the non-stationarity of residuals. Representative models from every tables have undergone with residual tests. Appendix 3 presents the residual plots of the models used.

\section{SUMMARY, CONCLUSION AND IMPLICATIONS}

\subsection{Summary and Conclusion}

Existing evidence on the poverty impact of public investment is hardly conclusive. The case for a rise in public investment needs to be assessed on a countryby-country basis, according to the structure of its economy and its initial physical public capital stock. Our results on poverty reduction are based on data currently available. We highlighted the limitations of these data series, both in terms of coverage/scope and accuracy. A fundamental direction for future research is to try to remove the obstacles. More work should be devoted to examine the limitations and inadequacies of the various time series data needed to study growth dynamics in the early transition years. For instance, recalculations or revaluations of the capital stocks are desirable and, in doing so, it is important to disentangle the roles of public and private investment. More reliable estimates of physical and human capital and labour contributions to growth will improve our understanding of the sources of this process and the relative roles of various crucial factors affecting growth, poverty reduction, and more equitable distribution.

In economic literature, strong argument exists for governments in developing countries to implement considerable public investment in raising the economic growth rate. In similar front, this study has examined the impact of public investment on economic growth and poverty reduction in major transition economies using the panel data for 1995-2010 -- the major transition period. We have created two dummies (Dm1 and Dm2) to refer two specific groups of countries. One group (Dm1) consists of eight countries which joined the EU (Czech Republic, Estonia, Hungary, Latvia, Lithuania, Poland, Slovakia, Slovenia), and the other group (Dm2) of four Asian countries (Cambodia, China, Laos and Vietnam). When these dummies are not used in the model, the regression refers to the whole set of countries used in the database. Likewise, from the whole period 1995-2010 under study, we have created two dummies - Dm3 for 1995-2000 and Dm4 for 20002006 - because these two periods refer to different phases of intensive transition. In addition to Ordinary Least Square regression, we have also applied Least Square Dummy Variable (LSDV) regression analysis in this study.

Empirical evidence from transition countries in this study concludes that the link between public investment and economic growth is positive and significant. Since there is more evidence that public capital is productive, this study reinforces the argument that it is even more productive if associated with increasing FDI. Although public investment shows very strong impact on economic growth in transition economies, its impact is still not strong enough in reducing poverty and poverty gap. But, public investment shows strong contribution to the improvement of human development index. This is evident from the significant positive relationship of educational expenses (a major part of public capital) with human development index in our regression analysis. Furthermore, public investment in general does not reduce inequality significantly; however, the public investments in health and education sectors do possess immense potentiality in inequality reduction in transition economies.

\subsection{Policy Implications}

Based on the availability of the data and econometric tools applied, the analysis between public 
investment and poverty as well as human development and inequality has explored some interesting findings that deserve important policy implications.

Public investment in transition economies is still not strong enough to reduce poverty, poverty gap and inequality in income distribution. In case of the inequality in income distribution, it is rather worsening because the growth has become pro-rich. But if public current expenditure is spent primarily on educational subsidies, this has pro-poor impact. More educational expenditure of the government is not only conducive to reduce poverty, poverty gap and improvement in human development index, but also reducing the income inequality.

Pertinent to these interrelationships, this study recommends the orientation of public current expenditures more towards educational expenditures in transition economies to make it supportive to poverty and inequality reductions as well as improvement in human development index.

Another important policy implication that follows from this study in that public investment is supportive to poverty reduction only if the public investment is raising overall growth in the transition economies. It has two implications, public investment should be supportive to private investment to raise the overall growth or there should be proper selection of the public sector projects that have high growth potentials. Therefore, project appraisal is necessary to select high growth public sector projects; social cost-benefit approach is instrumental in this regard.

\section{APPENDIX}

Table A1: Macroeconomic and Development Characteristics of Transition Economies (1995-2010)

\begin{tabular}{|c|c|c|c|c|c|c|c|c|c|c|c|c|c|}
\hline \multirow[t]{2}{*}{ Countries } & \multicolumn{13}{|c|}{ Major Macroeconomic and Development Indicators in Transition Economies (1995-2010) (Values in average) } \\
\hline & Gini & Pubedu & Pubhth & Liter & Pubcap & Growth & HDI & Pubcur & INF & Unpl & Prinv & FDI & TAX \\
\hline Albania & 31.38 & 3.27 & 2.33 & 97.32 & 6.21 & 5.81 & 0.72 & 9.67 & 6.51 & 15.75 & 17.72 & 4.58 & 15.42 \\
\hline Armenia & 35.20 & 2.67 & 1.59 & 99.48 & 1.39 & 7.30 & 0.69 & 11.10 & 15.94 & 32.33 & 26.08 & 5.72 & 13.37 \\
\hline Azerbaijan & 34.96 & 3.21 & 1.03 & 99.38 & 5.36 & 10.52 & 0.73 & 11.49 & 42.87 & 8.01 & 24.82 & 18.62 & 28.08 \\
\hline Belarus & 28.65 & 5.62 & 4.62 & 99.60 & 3.46 & 5.94 & 0.71 & 19.59 & 101.49 & & 23.93 & 1.83 & 18.97 \\
\hline Bulgaria & 28.90 & 3.78 & 4.06 & 98.20 & 3.71 & 2.36 & 0.75 & 17.28 & 77.73 & 12.35 & 16.84 & 9.99 & 19.70 \\
\hline Cambodia & 41.63 & 1.66 & 1.48 & 73.11 & 6.41 & 7.74 & 0.49 & 5.24 & 4.58 & 1.57 & 10.48 & 5.70 & 7.67 \\
\hline China & 41.50 & 1.87 & 1.95 & 92.60 & 26.90 & 9.94 & 0.62 & 14.37 & 3.94 & 3.63 & 11.72 & 3.87 & 7.88 \\
\hline Croatia & 30.68 & 4.07 & 6.02 & 98.49 & 3.71 & 3.05 & 0.78 & 21.42 & 4.27 & 12.42 & 18.29 & 4.67 & 21.39 \\
\hline $\begin{array}{c}\text { Czech } \\
\text { Republic }\end{array}$ & 25.82 & 4.14 & 5.96 & & 1.03 & 3.12 & 0.86 & 20.67 & 3.69 & 6.68 & 28.50 & 5.33 & 14.85 \\
\hline Estonia & 37.70 & 5.67 & 4.52 & 99.78 & 1.86 & 4.82 & 0.83 & 19.83 & 6.80 & 10.09 & 29.88 & 9.13 & 16.92 \\
\hline Georgia & 40.63 & 2.51 & 1.43 & 99.69 & 4.20 & 5.92 & 0.71 & 14.26 & 18.69 & 13.48 & 18.27 & 8.15 & 11.30 \\
\hline Hungary & 28.63 & 5.11 & 5.46 & 99.04 & 2.05 & 2.43 & 0.82 & 22.19 & 9.63 & 7.79 & 23.87 & 10.73 & 21.93 \\
\hline Kazakhstan & 33.36 & 3.18 & 2.41 & 99.6 & 3.17 & 5.48 & 0.71 & 11.64 & 24.77 & 9.72 & 20.19 & 8.26 & 11.58 \\
\hline $\begin{array}{l}\text { Kyrgyz } \\
\text { Republic }\end{array}$ & 35.05 & 5.06 & 2.92 & 98.97 & 5.51 & 3.95 & 0.60 & 18.21 & 16.04 & 8.78 & 13.97 & 4.26 & 13.26 \\
\hline Lao PDR & 34.45 & 2.36 & 1.57 & 67.82 & 3.92 & 6.69 & 0.48 & 7.49 & 23.26 & 2.00 & 18.53 & 3.68 & 8.65 \\
\hline Latvia & 34.99 & 5.53 & 3.71 & 99.77 & 3.66 & 4.09 & 0.79 & 20.26 & 8.08 & 12.61 & 23.16 & 4.67 & 14.61 \\
\hline Lithuania & 33.86 & 5.17 & 4.51 & 99.67 & 4.24 & 4.57 & 0.80 & 20.73 & 7.44 & 12.46 & 19.99 & 3.68 & 16.29 \\
\hline $\begin{array}{l}\text { Macedonia, } \\
\text { FYR }\end{array}$ & 37.99 & 4.17 & 5.06 & 96.70 & 4.95 & 2.50 & 0.70 & 19.54 & 4.53 & 34.11 & 12.58 & 4.24 & 19.16 \\
\hline Moldova & 36.49 & 7.03 & 4.69 & 97.59 & 2.27 & 2.41 & 0.63 & 18.55 & 16.37 & 7.29 & 19.49 & 5.29 & 16.48 \\
\hline Mongolia & 34.07 & 5.21 & 3.21 & 97.59 & 4.24 & 5.34 & 0.61 & 13.99 & 15.90 & 3.94 & 23.84 & 7.33 & 15.99 \\
\hline Poland & 33.64 & 5.20 & 4.36 & 99.47 & 1.10 & 4.56 & 0.79 & 18.03 & 6.91 & 13.68 & 21.65 & 3.76 & 16.62 \\
\hline Romania & 30.57 & 3.54 & 3.76 & 97.48 & 2.90 & 2.78 & 0.75 & 11.27 & 33.55 & 6.83 & 21.63 & 4.19 & 11.11 \\
\hline $\begin{array}{c}\text { Russian } \\
\text { Federation }\end{array}$ & 40.13 & 3.61 & 3.67 & 99.51 & 2.49 & 3.37 & 0.74 & 17.89 & 29.96 & 8.96 & 16.49 & 1.99 & 14.51 \\
\hline $\begin{array}{c}\text { Slovak } \\
\text { Republic }\end{array}$ & 27.27 & 4.05 & 5.30 & & 5.78 & 4.60 & 0.81 & 20.11 & 4.42 & 14.64 & 21.33 & 3.59 & 16.90 \\
\hline Slovenia & 30.79 & 5.56 & 6.08 & 99.67 & 1.53 & 3.34 & 0.87 & 18.76 & 6.68 & 6.38 & 26.21 & 1.93 & 20.05 \\
\hline
\end{tabular}




\begin{tabular}{|c|c|c|c|c|c|c|c|c|c|c|c|c|c|}
\hline \multirow[t]{2}{*}{ Countries } & \multicolumn{13}{|c|}{ Major Macroeconomic and Development Indicators in Transition Economies (1995-2010) (Values in average) } \\
\hline & Gini & Pubedu & Pubhth & Liter & Pubcap & Growth & HDI & Pubcur & INF & Unpl & Prinv & FDI & TAX \\
\hline Tajikistan & 31.01 & 2.89 & 1.18 & 99.57 & 7.39 & 5.13 & 0.56 & 14.83 & 74.09 & & 6.87 & 3.78 & 9.04 \\
\hline Turkmenistan & 40.77 & & 2.24 & 99.18 & 15.97 & 9.35 & 0.67 & 11.34 & 127.95 & & 16.06 & 7.18 & \\
\hline Ukraine & 29.08 & 5.11 & 3.72 & 99.4 & 2.63 & 1.52 & 0.71 & 20.23 & 44.91 & 8.66 & 18.74 & 3.35 & 14.17 \\
\hline Uzbekistan & 43.36 & & 2.70 & 99.01 & 6.02 & 5.49 & 0.61 & 18.87 & 56.83 & & 20.11 & 1.39 & 24.32 \\
\hline Vietnam & 36.01 & 5.94 & 1.91 & 91.2 & 2.66 & 7.31 & 0.56 & 6.75 & 8.42 & 2.34 & 30.93 & 6.24 & 20.66 \\
\hline Average & 34.56 & 4.22 & 3.45 & $95 / 51$ & 4.65 & 5.05 & 0.70 & 15.85 & 26.96 & 10.68 & 20.18 & 5.56 & 15.89 \\
\hline
\end{tabular}

Note:

Gini $=$ Gini inequality coefficient

Pubedu = Public expenditure in education (\% of GDP).

Pubhth = Public expenditure in health ( $\%$ of GDP).

Liter $=$ Literacy rate (in \%)

Pubcap = Public capital expenditure (\% of GDP).

Growth = Growth rate (in \%).

$\mathrm{HDI}=$ Human Development Index (HDI).

Pubcur = Public current expenditure $(\%$ of GDP).

INF = Rate of inflation (in \%).

Unpl = Rate of unemployment (in \%).

Prinv $=$ Private investment $(\%$ of GDP $)$.

FDI = Foreign Direct Investment ( $\%$ of GDP).

$\mathrm{TAX}=$ Tax revenue $(\%$ of GDP).

Table A2: Correlation Matrix among the Variables Used in the Models

\begin{tabular}{|c|c|c|c|c|c|c|c|c|c|c|}
\hline & Gini & Pubedu & Pubhth & Liter & Pubcap & Growth & HDI & Pubcur & Inf & Gsav \\
\hline Gini & 1 & & & & & & & & & \\
\hline Pubedu & -0.1472 & 1 & & & & & & & & \\
\hline Pubhth & -0.3741 & 0.6535 & 1 & & & & & & & \\
\hline Liter & -0.2075 & 0.5587 & 0.4505 & 1 & & & & & & \\
\hline Pubcap & 0.2716 & -0.3087 & -0.3101 & -0.0472 & 1 & & & & & \\
\hline Growth & 0.1528 & -0.261 & -0.3438 & -0.112 & 0.2373 & 1 & & & & \\
\hline HDI & -0.3457 & 0.3903 & 0.6985 & 0.7594 & -0.2433 & -0.1475 & 1 & & & \\
\hline Pubcur & -0.2405 & 0.6481 & 0.7164 & 0.6386 & -0.1115 & -0.3087 & 0.5761 & 1 & & \\
\hline Inf & -0.0006 & -0.0844 & -0.0742 & 0.074 & -0.0492 & -0.3139 & -0.132 & -0.0429 & 1 & \\
\hline Gsav & 0.0918 & -0.0002 & -0.0242 & 0.3714 & 0.4117 & 0.2822 & 0.1132 & -0.0612 & 0.0319 & 1 \\
\hline
\end{tabular}

\section{Appendix A3: Residual Tests}

Model 3, Table 1:

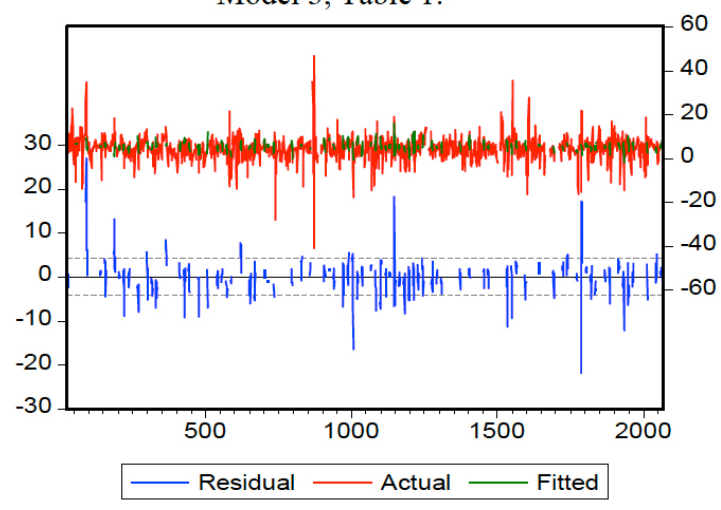

Model 7, Table 2:

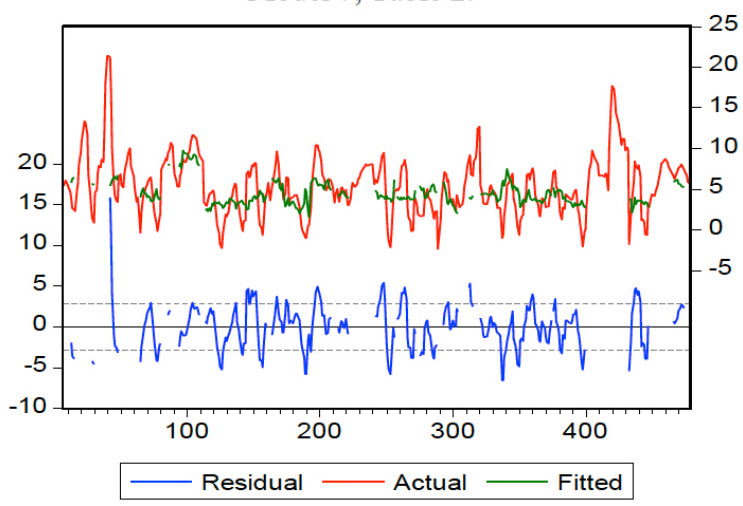




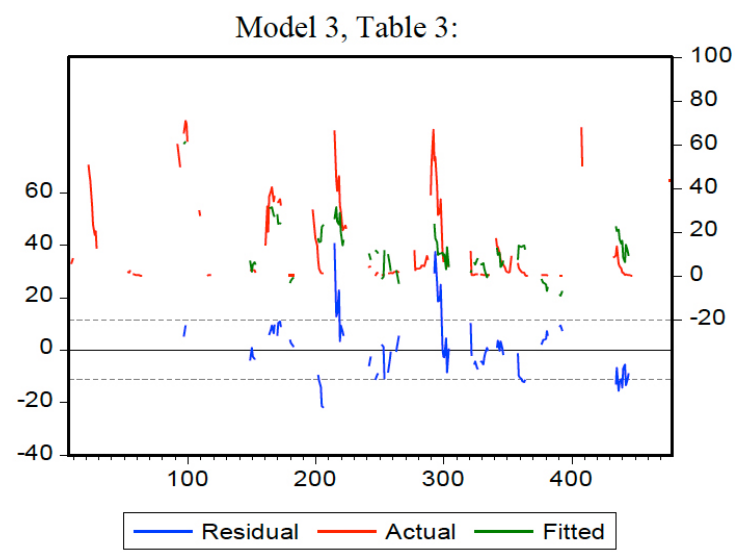

Model 4, Table 5:

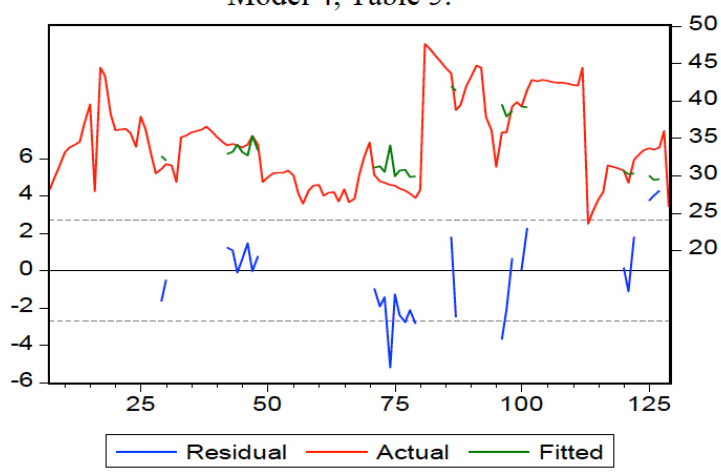

\section{REFERENCES}

Acharya S. and Cohen S., 2008. "Trade liberalization and household welfare in Nepal", Journal of Policy Modeling, 30: 10571060.

http://dx.doi.org/10.1016/j.jpolmod.2007.12.005

Agénor P.R., 2004. "The Economics of Adjustment and Growth", second ed., Harvard University Press, Cambridge.

Agénor P.R., 2008. "Fiscal policy and endogenous growth with public infrastructure", Oxford Economic Papers, 60(1): 57-87. http://dx.doi.org/10.1093/oep/gpm018

Aschauer D., 2000. "Public Capital and Economic Growth: Issues of Quantity, Finance and Efficiency", Economic Development and Cultural Change, 48 (2): 391-406. http://dx.doi.org/10.1086/452464

Barro R., 1990. "Government Spending in a Simple Model of Endogenous Growth", Journal of Political Economy, 98 (5): S103-S125. http://dx.doi.org/10.1086/261726

Barro R., 1991. "Economic Growth in a Cross Section of Countries", Quarterly Journal of Economics, Vol. 106: pp. 407-43. http://dx.doi.org/10.2307/2937943

Binswanger $H_{\text {., }}$ Khandler $S$. and Rosenzweig M., 1993. "How Infrastructure and Financial Institutions Affect Agricultural Output and Investment in India", Journal of Development Economics, 41: 337-66. http://dx.doi.org/10.1016/0304-3878(93)90062-R

Calderon C. and Serven L., 2004. "The Effects of Infrastructure Development on Growth and Income Distribution", Policy Research Working Paper No 3400.

Canning D. and Fay M., 1993. "The Effects of Transportation Networks on Economic Growth", Working paper, Department of Economics, Columbia University.
Model 3, Table 4:

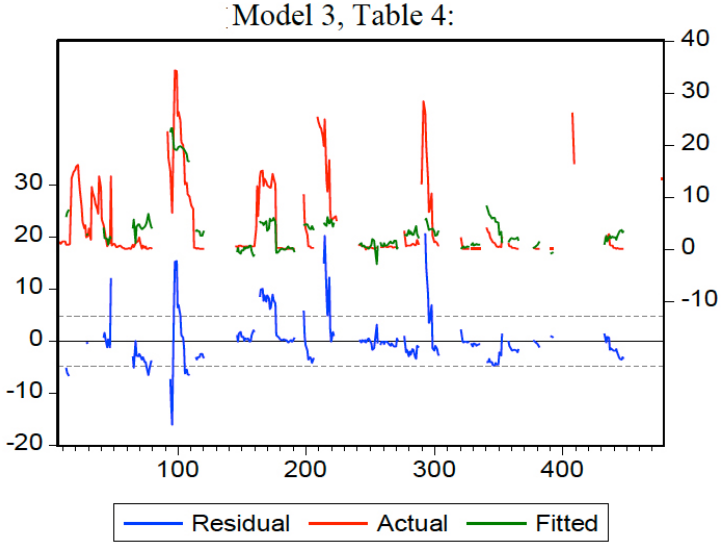

Model 3, Table 6:

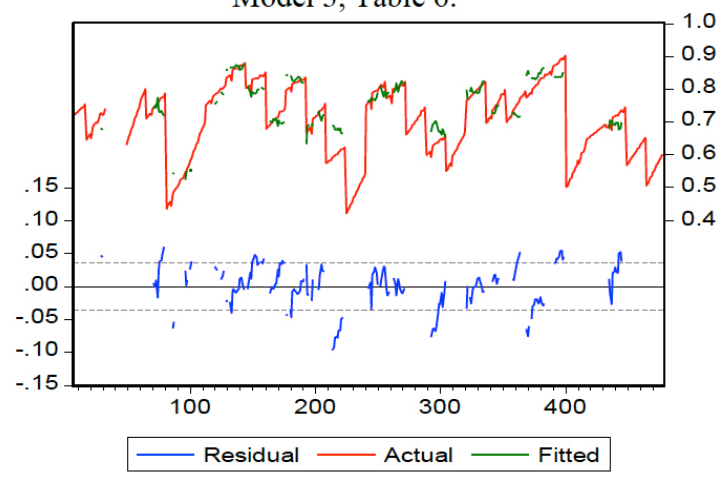

Canning D. and Bennathan E., 2000. "The Social Rate of Return on Infrastructure Investments", Policy Research Working Paper No 2390, Washington, DC, World Bank.

Cincera M. and Pamukçu M., 2007. "Foreign firms and technology spillovers in developing countries: the Turkish case", UN UMERIT Conference on Micro Evidence on Innovation in Developing Economies, Maastricht, Netherlands.

Commission on Growth and Development, 2008. "The Growth Report: Strategies for Sustained growth and Inclusive Development", IBRD/ The World Bank.

Congressional Budget Office, 2012. "Estimated Impact of the American Recovery and Reinvestment Act on Employment and Economic Output from October 2011 through December 2011". http://www.cbo.gov/publication/43013

Council of Economic Advisers, 2010. "The Economic Impact of the American Recovery and Reinvestment Act of 2009: Fourth Quarterly Report". http://www.whitehouse.gov/files/ documents/cea_4th_arra_report.pdf

Datt G. and Ravallion M., 2002. "Is India's Economic Growth Leaving the Poor Behind?", Journal of Economic Perspectives, 16 (3) 89-108. http://dx.doi.org/10.1257/089533002760278730

Devarajan S., Swaroop V. and Zou H., 1996. "The Composition of Public Expenditure and Economic Growth", Journal of Monetary Economics, 37: 313-44. http://dx.doi.org/10.1016/S0304-3932(96)90039-2

Durham, J.B., 2004. "Absorptive Capacity and the Effects of FDI and Equity foreign portfolio investment on economic growth", European Economic Review, 48: 285-306. http://dx.doi.org/10.1016/S0014-2921(02)00264-7

Easterly W., 2001. "The Elusive Quest for Growth: Economists, Adventures and Misadventures in the Tropics", London, MIT Press. 
EBRD, 2007. "Institutions, Markets and Economic Performance: What drives growth in the transition countries?", Special Report, http://www.ebrd.com/pages/research/analysis/ publications.shtml

Fan S., Hazell P. and Thorat S., 1999. "Linkages between Government Spending, Growth and Poverty in Rural India", Research Report 110, Washington, DC, IFPRI.

Fan S., Zhang L. and Zhang X., 2002. "Growth, Inequality and Poverty in Rural China: The Role of Public Investments", Research Report 125, Washington, DC, IFPRI.

Fedderke J. and Bogetic Z., 2009. "Infrastructure and growth in South Africa: direct and indirect productivity impacts of 19 infrastructure measures", World Development, 37(9): 15221539. http://dx.doi.org/10.1016/j.worlddev.2009.01.008

Gomanee K., Morrissey O., Mosley P. and Verschoor A., 2003. "Aid, Pro-poor Government Spending and Welfare", Research Paper 3, Nottingham, University of Nottingham, CREDIT.

Gramlich E., 1994. "Infrastructure Investment: A Review Essay", Journal of Economic Literature, 32: 1176-96.

Gupta S., Clements B., Baldacci E. and Mulas-Granados C., 2002. "Expenditure Composition, Fiscal Adjustment, and Growth in Low-income Countries", IMF Working Paper No 02/77.

Hall R., 2009. "By How Much Does GDP Rise If the Government Buys More Output?", Brookings Papers on Economic Activity, Fall: pp. 183-231 http://dx.doi.org/10.1353/eca.0.0069

Heller, P. S., 2005. "Understanding Fiscal Space", IMF Policy Discussion Papers.

King R.G., Plosser C.I., Stock J.H., Watson M.W., 1991. "Stochastic trends and economic fluctuations", American Economic Review, 81(4): 819-840.

Levine R. and Renelt D., 1992. "A Sensitivity Analysis of Crosscountry Growth Regressions", American Economic Review, 82 (4): 942-63.

Milbourne R., Otto G. and Voss G., 2003. "Public Investment and Economic Growth", Applied Economics, 35: 527-40. http://dx.doi.org/10.1080/0003684022000015883
Mitra A., Varoudakis A. and Veganzones M.-A., 1998. "Productivity Growth and Technical Efficiency in the Manufacturing Industry of the states of India. The Role of Infrastructure", Revue Economique, 49 (3): 845-55. http://dx.doi.org/10.2307/3502814

Moosa I.A., 2002. "FDI: Theory, Evidence and Practice", New York Palgrave.

Mosley P., Hudson J. and Verschoor A., 2004. "Aid, Poverty Reduction and the "New Conditionality", Economic Journal, 114, June: F217-F243. http://dx.doi.org/10.1111/j.1468-0297.2004.00220.x

Pritchett L., 2000. "The Tyranny of Concepts: CUDIE (cumulated, depreciated, investment effort) is not Capital", Journal of Economic Growth, 5: 361-84. http://dx.doi.org/10.1023/A:1026551519329

Roy R., Heuty A., and Letouze E., 2006. "Fiscal Space for Public Investment: Towards a Human Development Approach", Paper Prepared for the G-24 Technical Meeting, Singapore.

Sala-i-Martin X., 1997. "I Just Ran Two Million Regressions", American Economic Review, 87 (2): 178-83.

Tsoukis C. and N. Miller., 2003. "Public Services and Endogenous Growth", Journal of Policy Modeling, 25: 297-307. http://dx.doi.org/10.1016/S0161-8938(03)00026-7

Turnovsky S. J., 2000. "Government policy in a stochastic growth model with elastic labor supply", Journal of Public Economic Theory, 2(4): 389-433 http://dx.doi.org/10.1111/1097-3923.00044

UNCTAD, 1999. "Foreign Direct Investment and the Challenge of Development", Geneva, United Nation Publication.

Woodford M., 2011. "Simple Analytics of the Government Expenditure Multiplier", American Economic Journal, 3:1-35. http://dx.doi.org/10.1257/mac.3.1.1

Zandi M., 2011. "An Analysis of the Obama Jobs Plan", Moody's Analytics Dismal Scientist, online publication, September 9

Received on 03-03-2016 Accepted on 19-04-2016

Published on 20-09-2016

DOI: http://dx.doi.org/10.6000/1929-7092.2016.05.27

(C) 2016 Acharya and Nuriev; Licensee Lifescience Global.

This is an open access article licensed under the terms of the Creative Commons Attribution Non-Commercial License (http://creativecommons.org/licenses/by-nc/3.0/) which permits unrestricted, non-commercial use, distribution and reproduction in any medium, provided the work is properly cited. 